\begin{tabular}{llr} 
KULTURA & POLSKA A KADEMIA NAUK & ISSN 0023-5172 \\
i & KOMITET SOCJOLOGI & $2300-195 \mathrm{x}$ \\
SPOLCZENSTWO & $\begin{array}{l}\text { INSTYTUT STUDIÓW POLITYCZNYCH } \\
\text { 2020, nr 2 ANTROPOLOGIA ZAANGAŻOWANA }\end{array}$ & \\
\hline
\end{tabular}

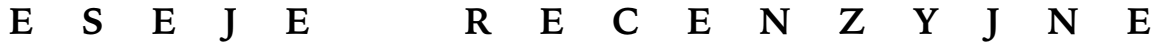

SEBASTIAN LATOCHA

Uniwersytet Łódzki

\section{SPÓŹNIONY GOŚĆ W CUDZYM ŚWIECIE: KONTEKSTY TRUDNEGO DZIEDZICTWA}

Pusty las Moniki Sznajderman to nietradycyjna monografia wsi Wołowiec (Beskid Niski, Łemkowszczyzna), która została w niej sportretowana z perspektywy bycia gościem. Autorka przeprowadziła się tutaj ze stolicy i spędziła połowę życia. W 1996 roku założyła Wydawnictwo Czarne.

Bycie gościem realizuje się tylko $\mathrm{w}$ relacji $\mathrm{z}$ miejscem i gospodarzami, którzy w gościnę przyjmują. Pusty las przypomina nam, że zawsze jesteśmy c zyi miś gośćmi, że zawsze bawimy u kogoś w gościnie. W Wołowcu gospodarzami „są” Łemkowie, którzy jednak nie zaprosili gości do siebie; ci wprosili się sami pod ich nieobecność. Sznajderman problematyzuje sytuację egzystencjalną, w której „przybysze z daleka” zajmują miejsce gospodarzy. Goście mogą wziąć w opiekę cudzą historię lub o niej zapomnieć. Mogą rozgościć się pośród resztek lub zatrzeć ślady cudzej obecności. Mogą - jak pisze Maria Stiepanowa w eseju Pamięci pamięci (2020, s. 108) „oddychać powietrzem postpamięci".

Pusty las to narracja lokująca się na granicy nauki (etnografii, antropologii kultury) i sztuki (literatury, reportażu). Z jednej strony mamy jasno przedstawiony problem, solidną bibliografię (np. Heidegger, Le Goff, Okely) i źródła archiwalne, z drugiej - impresyjne fotografie Wołowca, $\mathrm{w}$ tonacji ciemnej zieleni, granatu i czerni, oraz eseistyczny, osobisty ję-

Adres do korespondencji: sebastian.latocha@uni.lodz.pl; ORCID: 0000-0003-4226$-9131$ 
zyk autorki, która obywa się bez humanistycznej nowomowy, język jakby bazujący na Geertzowskich „pojęciach bliskich doświadczenia” ${ }^{1}$ i wiedzy lokalnej (Geertz 2005). W recenzji wydawniczej Pustego lasu Roch Sulima pisze:

„Najważniejszą sprawą wydaje się jednak to, że Monika Sznajderman bliska jest odnalezienia języka, w którym może rozmawiać z nieobecnymi, z jej nieznanymi sąsiadami. Ten język jest widzeniem "przez nicość», przybliżaniem się do świata z czułością, a nie widzeniem-władaniem. To bardzo ważne w czasach, gdy pamięć staje się towarem"2.

Sznajderman, autorka antropologicznych książek, takich jak Zaraza. Mitologia dżumy, cholery i AIDS (1994) czy Błazen. Maski i metafory (2014), tym razem swój aparat naukowy i etnograficzny warsztat ukrywa, stosując konwencję przypominającą reportaż literacki. Nie pisze wprost o auto-antropologii, o postpamięci, o trudnym i dysonansowym dziedzictwie, o Raju Utraconym, a jednak Pusty las jest właśnie o poczuciu zobowiązania do współodczuwania i zadośćuczynienia — autorka bazuje na własnym doświadczeniu bycia gościem w świecie gospodarzy, których nie ma w fizycznym krajobrazie. W innym kontekście Georges Perec (2012, s. 201) konstatuje: „pamięć, która dotyczy nas, choć nie jest nasza, ale która jak by to ująć, sytuuje się obok naszej i określa nas niemal tak samo, jak nasza własna historia". Taka wydaje się pamięć spóźnionego gościa w cudzym świecie.

„W Wołowcu, jak już napisałam, nie kupiłam łąki i nie przeniosłam na nią domu — zbudowałam własny. Mieszkam w nim od dwudziestu kilku lat i chciałabym zostać do końca. Choć nie mogę się nadziwić, co tu właściwie robię, w tej «ruskiej okolicy», na wysiedlonej Łemkowszczyźnie, wśród zrujnowanych cerkwi i zdziczałych sadów, cmentarzy z pierwszej wojny światowej i czarnych kiwonów - jedynych śladów po zapomnianym naftowym imperium — wśród cudzych chałup i cudzych rzeczy, w cudzym

${ }^{1}$ Geertzowskie pojęcia bliskie doświadczenia to koncepcja, którą „pacjent, podmiot lub w tym przypadku informator - mógłby samodzielnie, bez wysiłku i w sposób naturalny spożytkować do zdefiniowania tego, co on czy jego współplemieńcy widzą, czują, myślą, wyobrażają sobie itd. i która byłaby dla niego czytelna, gdyby inni się nią posługiwali. Koncepcja daleka od doświadczenia natomiast byłaby tą, którą taki czy inny specjalista — analityk, eksperymentator, etnograf, a nawet ksiądz czy ideolog — wykorzystuje do sformułowania swoich naukowych, filozoficznych czy praktycznych celów. [...] Ludzie posługują się koncepcjami bliskimi doświadczenia spontanicznie, nieświadomie, jak gdyby potocznie; nie zdają sobie sprawy, prócz wyjątkowych i ulotnych momentów, że jakiekolwiek «koncepcje» wchodzą tutaj w grę" (Geertz 2005, s. 64-65).

${ }^{2}$ Cytat pochodzi z recenzji wydawniczej Rocha Sulimy, której część znajduje się na okładce Pustego lasu. 
pejzażu podpierającym niskie niebo. Dziecko żydowsko-polskie z tak zwanej inteligenckiej rodziny, «inteligencja pracująca», mówiono w tamtych dziwnych czasach, dziewczyna z warszawskiego Nowego Światu i okolic, panna do spodu miejska, jak wieś, to tylko wakacje albo wczasy pod gruszą, przecież się tam zanudzisz i uciekniesz, a gdzie kino, gdzie teatr, gdzie koncert, mówili znajomi, którzy zawsze wiedzą lepiej, gdzie kawiarnia i wystawa, gdzie kariera naukowa albo choć jakaś praca. I przecież ty w ogóle nie znasz wsi, oziminy od jarego nie odróżnisz, w piecu nie napalisz. [...] Trudno wyjaśnić tę ciemną siłę przyciągania, która w końcu zwyciężyła nad wszelkim rozsądkiem, wytrąciła mnie $z$ trajektorii oczywistego życia i wyciągnęła z Warszawy na to odległe pustkowie z mroczną przeszłością, wyboistą teraźniejszością i niczego nieobiecującą przyszłością" (Sznajderman 2019, s. 23, 24).

Dla Sznajderman etnografia to doświadczenie osobiste. Nie chowa się za scjentycznymi konstrukcjami języka, nie ukrywa, że pisze o sobie i przez siebie. Jest to auto-antropologiczna monografia Wołowca, w której autorka świadomie figuruje siebie jako gościa - Innego, Obcego. Uzmysławiając sobie, że właśnie nim jest, autoironicznie podkreśla swoje kulturowe niedopasowanie do wsi, będące przedmiotem dobrych rad „znajomych, którzy zawsze wiedzą lepiej".

Ryszard Kapuściński (2013, s. 22) z dystansu, czyli spoza etnografii bilansując antropologiczne status quo, konstatuje: „antropologia jest zwrócona w stronę Innego, jemu wyłącznie poświęcona". Choć Sznajderman nie wchodzi w dyskurs z Kapuścińskim, ani go nie cytuje, to odwraca jego perspektywę, akceptując fakt, że to ona - gość, etnografka, antropolożka - jest tutaj Obcym w krajobrazie kulturowym Wołowca. Pusty las jest wyraźnym przykładem ekscentrycznego „proroctwa” Kirsten Hastrup (2008, s. 171): „dziś przyszedł czas, że odwracamy koncepcję «czynienia obcym» ku nam samym. Teraz antropologia powinna zająć w świecie miejsce «radykalnie obcego»". W ślad za tą konstatacją idzie pozytywna propozycja metodologiczna: „lokalne kategorie nie wyczerpują świata, a głosy tubylców nigdy nie opowiadają całej historii o świecie. Łączy się to z faktem, że dla tubylców ich kultura jest referencyjnie przezroczysta. Nie widzi się jej, a patrzy przez nią" (Hastrup 2008, s. 162). Wydawałoby się, że dystans, jaki w Pustym lesie dzieli gościa od nieobecnych „tu i teraz” gospodarzy, osłabia „prawdziwość” i „etnograficzność” monografii Wołowca, ale Sznajderman znajduje wyjście $z$ tej sytuacji:

„Dlatego staram się przywrócić krajobrazowi przeszłość, a jego twórcom — imiona i nazwiska, choćby niektóre, choćby kilka, tyle, ile zdołam. Przynajmniej do pewnego stopnia przestaną być bezimienną, bezosobową siłą, która przez stulecia wypalała i karczowała, orała i siała, sadziła i zbierała, 
i staną się konkretnymi ludźmi. Nazywają się Hatalewiczowie i Polańscy. Gybowie i Tuzowie. Drobczakowie i Smyjowie. Filakowie i Szczawińscy. A także Lorberowie i Binderowie, Bergmanowie i Kriegerowie, Sternowie i Zieglerowie. I jeszcze inni. Moi dawni sąsiedzi" (Sznajderman 2019, s. 32-33).

James Clifford, śledząc dynamikę autorytetu w etnografii / antropologii w XX wieku, komentuje kolejne style czy formy tego autorytetu doświadczalny, interpretacyjny, dialogiczny i polifoniczny (Clifford 2000, s. 29-63). Autorytet etnograficzny ${ }^{3}$ Pustego lasu nie bierze się jednak ani z doświadczenia w stylu Bronisława Malinowskiego, choć Sznajderman urzeczywistnia „życie w wiosce tubylczej” (Clifford 2000, s. 43), ani z interpretacji, choć Pusty las posiada wyraźną sygnaturę autorską, ani z dialogu, choć w geście stworzenia monografii Wołowca srebrzy się „proces dawania-i-brania" (Clifford 2000, s. 53), ani z polifonii. We współczesnej etnografii badacz burzy monofoniczność autorytetu przez obszerne cytowanie badanych. Dlaczego Sznajderman nie cytuje swoich gospodarzy, lecz jedynie napomyka o nich? „Chciałabym opowiedzieć o nich jak najwięcej, chciałabym opisać ich twarze i opisać ich życie, ale mogę je sobie tylko wyobrażać" (Sznajderman 2019, s. 34). Cytaty (podstawowe narzędzie dzisiejszej rzetelnej etnografii) zostają zastąpione karkołomną rekonstrukcją (ze śladów i resztek porzuconych w krajobrazie Wołowca) życia konkretnych ludzi, których imiona i nazwiska poznajemy.

„To napięcie między pragnieniem wywoływania po nazwisku a poczuciem, że tamtego świata nie da się przywołać, nawet z pomocą najlepszych źródeł i najczulszych narzędzi, nie daje o sobie zapomnieć, drażni i boli jak niezagojona rana. I wiem, że nic się z tym nie da zrobić, a przecież mimo to, z pełną świadomością wpisanego w ten projekt niespełnienia, czuję, że nie ma wyjścia, że trzeba próbować" (Sznajderman 2019, s. 34-35).

Autorytet etnograficzny Sznajderman opiera na... dekonstrukcji idei autorytetu. Autorka Pustego lasu dzieli się brakiem wiary w możliwość zrealizowania $\mathrm{w}$ pełni swojego szlachetnego projektu wdzięczności gościa wobec gospodarzy. Choć przedsięwzięcie jest utopijne, to nie zniechęca jej do podjęcia próby. Mamy do czynienia z badaczką z krwi i kości. Pokazuje ona „etnograficzną kuchnię”, w której mieszczą się prawdziwe emocje,

\footnotetext{
${ }^{3}$ Choć mam świadomość, że Pusty las nie jest do końca naukową książką etnograficzną (stanowi raczej przykład Geertzowskiego „zmąconego gatunku”), proponuję spojrzeć na nią przez pryzmat refleksji Clifforda na temat rodzajów autorytetu w etnografii, aby rzucić światło na walor książki Sznajderman, jakim jest rezygnacja autorki z konwencjonalnych metod konstrukcji autorytetu w antropologii.
} 
rozterki, demistyfikacja słabości własnego warsztatu badawczego, tego, z czym sobie nie radzimy jako antropolodzy zgłębiający problematykę dziedzictwa. Jednak — jak pisze — „nie ma wyjścia”, co stawia ją na pozycji gościa dziedziczącego po Łemkach nie tylko fizyczny krajobraz, lecz także postpamięć, która „gromadzi treści zapamiętane i tkwiące w świadomości, niepochodzące $z$ naszego własnego doświadczenia, ale $z$ doświadczenia naszych bliskich, którzy opowiadając o nim, przeżywali je z nami powtórnie" (Kaniowska 2014, s. 390). Postpamięć Sznajderman różni się jednak od koncepcji, którą proponuje Marianne Hirsch (1997) w autobiografii połączonej z refleksją natury teoretycznej. Jako gość w Wołowcu nie ma tam bowiem bliskich, z którymi mogłaby powtórnie przeżyć ich doświadczenie. Nie ma Łemków - gospodarzy. Autorka, dziedzicząc „pusty” krajobraz, wykształca w sobie charakterystyczne dla postpamięci „poczucie zobowiązania do współodczuwania i zarazem zadośćuczynienia. Poczucie to naznacza i obarcza postpamiętającego. Nie pozwala mu uwolnić się nie tylko od przekonania o koniecznej solidarności z osobą przekazującą mu swoją wiedzę o przeszłości i emocje, lecz także od przeświadczenia o obowiązku ich przechowania” (Kaniowska 2014, s. 390). „Nie powinnam o tym zapomnieć. Kim bowiem byłabym tu bez nich? Czym byłby bez nich mój dzisiejszy świat?" - pyta retorycznie Sznajderman (2019, s. 35).

Stiepanowa (2020, s. 106-107) twierdzi, że historia XX wieku „rozrzuciła po świecie zarzewia katastroficznych przemian i gros tych, którzy żyją, tak czy inaczej może uważać się za tych, którzy przeżyli: za rezultat traumatycznego przesunięcia, za jego ofiary i spadkobierców, którzy mają co wspominać i powoływać do życia za cenę własnego teraz". Sznajderman wydaje się właśnie spadkobierczynią długu tego rodzaju. „Świat żywych dodaje Stiepanowa (2020, s. 107) — koreluje ze światem martwych: śpimy w ich domach i jemy z talerzy, które zapomniały poprzednich właścicieli". W tym sensie autorka Pustego lasu jest także świadkiem i uczestniczką katastrofy. Stiepanowa (2020, s. 106) określiłaby jej kondycję mianem nie tyle postpamięci, ile nowej pamięci ${ }^{4}$.

„Wszyscy oni są na cmentarzu, tym starym, przycerkiewnym, i tym nowszym, leżącym nieco dalej. W myślach nazywam ten skryty w cieniu cerkwi ciemnym, a ten drugi, wystawiony na południowe słońce, jasnym. Stary zamknięto z braku miejsc około 1920 roku. Na powierzchni zostało ledwie kilkanaście nagrobków z żeliwnymi i kamiennymi krzyżami. Wśród nich

${ }^{4}$ Stiepanowa nie definiuje pojęcia „nowa pamięć”; jego pole semantyczne określa w całym eseju Pamięci pamięci. 
Piotra Hutyriaka, Rozalii Hutyriak, Oleny Kowal, Zofii Hatalewicz, Teodora Fila, Konrada Sydoriaka, rodziny Kołotyłów. A przecież leży tam też Paweł Dudycz, syn Teodora. W 1778 roku — gdy zmarł — miał ledwie dziewięć lat. [...] Albo kiedy ciemnym listopadowym wieczorem idę przez uśpioną wieś i słychać tylko szczekanie psów, pachnie wilgocią, zbutwiałymi liśćmi i dymem, a jedyne światła, jakie się palą, palą się właśnie na cmentarzu. U moich podziemnych sąsiadów, u moich zmarłych znad Zawoi. U Marianny, Mikołaja i Kseni. U Wasyla, Jana i Damiana. U zmarłej w 1904 roku Anny o nazwisku, którego na wytrawionym deszczem i upływem czasu szarym piaskowcu nie potrafię odczytać. Z jej nagrobnego pomnika odpadł krzyż, leży w kilku kawałkach wśród barwinka i jesiennych liści. Porośnięty zielonym mchem kamień wrasta w ziemię" (Sznajderman 2019, s. 68, 70).

Pisząc o Wołowcu, który przeminął, Sznajderman sięga do dziewiętnastowiecznych źródeł etnograficznych, prasy (np. „Gazeta Lwowska”), ksiąg parafialnych i innych archiwaliów, epitafiów i cmentarzy, co zbliża jej przedsięwzięcie do archeologii współczesności i archeologii krajobrazu. Michał Okoński (2019, s. 29) pisał o Pustym lesie:

„Z jednej strony jej książka przypomina odprawianie dziadów po tych, którzy - no właśnie nie wiadomo, odeszli czy nie odeszli, bo mimo iż Monika prowadzi teraz pod górę, na jeden z tutejszych cmentarzy, gdzie stoi kilkanaście nagrobków, to przecież pamiętam zdanie o księgach parafialnych zachowanych w przemyskim archiwum, dzięki którym może wiedzieć, «że głęboko pod ziemią ukryta jest inna wieś, że żyje swoim życiem podziemny wołowiecki świat»".

Porastanie mchem konotuje zapomnienie (Macdonald 2009, s. 7-8), a to bywa rewersem trudnego dziedzictwa...

„Chciałabym widzieć, jak się szykują, ci moi nieznani sąsiedzi sprzed wieku, którzy zniknęli bym miała tu miejsce, jak u agentów kupują bilety na kolej i statek. [...] W 1900 roku na cmentarzu w Nieznajowej stanie kamienny krzyż ufundowany na chwałę bożą przez zarobkowych emigrantów w Ameryce. Niektórzy wrócą, pospłacają długi, pobudują domy, które niebawem i tak zabiorą im lub spalą w kolejnych dziejowych zawieruchach. Ale wielu nie powróci. Po latach ich dzieci przyjadą do Wołowca w poszukiwaniu korzeni" (Sznajderman 2019, s. 125, 128-129).

Kilkadziesiąt stron Pustego lasu to empatyczny, czuły opis społecznych i ekonomicznych kontekstów emigracji Łemków z Wołowca (i Beskidu Niskiego w ogóle) do Ameryki w XIX i na początku XX wieku; opis galicyjskiej biedy, nieurodzaju i chorób, które kontrastują z kuszącym amerykańskim snem. Sznajderman śledzi tułacze losy emigrantów i emigrantek z Wołowca, jest z nimi u nieuczciwych agentów, pomaga się pakować, 
asystuje przy wszywaniu pieniędzy w ubrania, towarzyszy im na statku w paradoksalnej samotności w ścisku i tłumie, przeżywa chorobę morską, pracuje z mężczyznami w przemyśle ciężkim w Ansonii i w kopalni w Bonne Terre, a $z$ kobietami — w przędzalni.

„W 1945 roku dawnych mieszkańców Wołowca wyrwano więc nagle z ich życia, odebrano im świat, w którym dorastali, żyli i umierali. [...] Akcja «Wisła» była krótka: rozpoczęła się 28 kwietnia 1947 roku o czwartej rano i trwała do 31 lipca, trzy miesiące. [...] Wygnano tych, których nie uważano za Polaków, tylko za wrogów" (Sznajderman 2019, s. 195, 210).

Jednak nie fakty dotyczące Akcji „Wisła” są wartością Pustego lasu, lecz psychologiczne, emocjonalne oblicze powojennej historii Łemków. Różnica między perspektywą Sznajderman a antropologiczną refleksją nad łemkowskim Rajem Utraconym Beaty Wasilewskiej-Klamki — będącą w polskiej humanistyce jednym z głównych etnograficznych głosów o kulturowym wymiarze Akcji „Wisła” - polega na tym, że pierwsza akcentuje krzywdę ludzką, druga — zgłębia topos Raju Utraconego w kontekście sytuacji Łemków po drugiej wojnie światowej w Polsce (Wasilewska-Klamka 2006); wydaje się, że pierwsza jest bliżej ludzi i ich problemów, druga bliżej kultury, antropologicznych konstrukcji, kategorii małej ojczyzny i ojczyzny prywatnej.

„Mogę tu mieszkać, bo ich wszystkich nie ma. Wyjechali. Zostawili po sobie pustkę, a w niej wspomnienia i porzucone rzeczy, zostawili krajobraz, który przez lata tworzyli. Przecież to oni zawsze tu żyli, nie ja. [...] Spóźniony gość w cudzym świecie, przybysz z daleka urządzający się na nieswoim. [...] Pamięć o moich zmarłych sąsiadach, tych, którzy leżą u stóp cerkwi i trochę dalej, na słonecznym zboczu, zniszczyła historia — zmiotła żywych ludzi z miejsca, w którym żyli, i rozrzuciła ich po świecie. [...] Więc rzeczy - wehikuły pamięci - zinwentaryzowane i zabezpieczone, trafią do nowych właścicieli albo rozpadną się tu, na miejscu, każda inaczej, zależnie od materii, z której ją stworzono" (Sznajderman 2019, s. 33, 34, 76, 192).

Łemkowie zniknęli $z$ Wołowca po drugiej wojnie światowej w wyniku Akcji „Wisła”, czego efektem ubocznym jest dziś trudne dziedzictwo - materialne („porzucone rzeczy”) i niematerialne („wspomnienia”). W teorii trudne dziedzictwo (difficult heritage) to przeszłość będąca po latach przedmiotem kontestacji lub przeszłość dezawuowana, niewygodna dla bieżącej autoidentyfikacji, przeszłość, która generuje napięcia społeczne (Macdonald 2009, s. 1). Podobny wydźwięk ma dysonansowe dziedzictwo (dissonant heritage), którego istotą jest to, że różne, ambiwalentne oceny przeszłości otwierają perspektywę niezgodności w kwestii dziedzictwa (Dragićewić-Šešić, Rogač-Mijatović 2014, s. 11). Dysonans pojawia 
się, gdy różne podmioty kreują własne dyskursy dotyczące miejsc dziedzictwa kulturowego (Battilani, Bernini, Mariotti 2018, s. 1417). Cechuje to Wołowiec jako miejsce, w którym różne formy pamięci i zapomnienia, aktywne i pasywne, krzyżują się, a nie składają się na wspólną interpretację przeszłości. Z jednej strony nostalgiczne podróże ludzi, którzy przyjeżdżają do Wołowca w poszukiwaniu swoich korzeni oraz piękne gesty pamięci gości w tym krajobrazie kulturowym (np. właśnie Pusty las), a z drugiej - weekendowe wycieczki i szlaki turystyczne po Łemkowszczyźnie miejscu dysonansowego dziedzictwa (Battilani, Bernini, Mariotti 2018, s. 1418) - oraz obiekty, po których nie ma śladu. W praktyce trudne dziedzictwo skutkuje okolicznościami, w których hałaśliwi turyści pojawiają się jako „nieoczekiwany kolorowy motyw na zetlałej tkaninie krajobrazu” (Sznajderman 2019, s. 66), nie mając pojęcia, że pod cienką skórą turystycznego produktu bulgoce i kipi trudna, bolesna historia.

„Trudzę się więc, troszczę i uprawiam, krzątam i sprzątam, sadzę i koszę do pejzażu, w którym przyszło mi żyć, dokładam nowe elementy i z każdym najdrobniejszym gestem zmieniam go na zawsze. Na rozmaite sposoby rzeźbię w materii mojej wsi, do trwań jej niegdysiejszych mieszkańców dolepiam moje trwanie, na ich śladach odciskam swój ślad" (Szanjderman 2019, s. 30).

Dla Sznajderman wzięcie w opiekę cudzej historii i krajobrazu to nie ochrona, konserwacja, skansenizacja dziedzictwa (Banaszkiewicz i in., 2012) czy romantyczne odprawianie dziadów. To pamięć i refleksyjna kontynuacja, którym $-z$ jednej strony — asystuje melancholia: autorka jakby reaktywuje w Pustym lesie literacki topos ubi sunt, po kolei wywołując po nazwisku gospodarzy, którzy goszczą ją w Wołowcu. Natomiast z drugiej strony - gość mości się, urządza, gospodaruje, przekształca, wydeptuje własne ścieżki i naznacza je swoim zapachem, kładąc nową warstwę palimpsestu.

W podsumowaniu pragnę stwierdzić, że książka Sznajderman jest kolejnym dobrym przykładem „etnografii poza etnografią”. Pusty las wydaje się egzemplifikacją Geertzowskiego gatunku zmąconego — „nowej formuły myśli społecznej” (Geertz 2005, s. 29). Problemy antropologiczne (m.in. tożsamość, pamięć, dziedzictwo) zostały tutaj zgłębione w formule reportażu literackiego czy śledczego. A może najwyższy czas, aby wyodrębnić, nazwać, czyli określić egzystencję reportażu antropologicznego? Próbą był artykuł Anny Wróblewskiej (2017), w którym autorka na przykładzie Czar- 
nego ogrodu Małgorzaty Szejnert (2016) opisała reportaż historyczny jako rodzaj współczesnej etnografii. Książka Sznajderman zachęca do powołania nowego gatunku literatury / nauki.

\section{BIBLIOGRAFIA}

Banaszkiewicz Magdalena, Matusiak Agnieszka, Hochleitner Janusz, von Rohrscheidt Armin Mikos, Kruczek Zygmunt, Gaweł Łukasz, Dąbrowski Dariusz, Jarnecki Michał, 2012, Problem „skansenizacji” dziedzictwa kulturowego w turystyce, „Turystyka Kulturowa”, nr 1, s. 88-95.

Battilani Patrizia, Bernini Cristina, Mariotti Alessia, 2018, How to Cope with Dissonant Heritage: A Way Towards Sustainable Tourism Development, „Journal of Sustainable Tourism”, t. 26(8), s. 1417-1436.

Clifford James, 2000, Kłopoty z kulturą. Dwudziestowieczna etnografia, literatura i sztuka, tłum. Ewa Dżurak i in., Wydawnictwo KR, Warszawa.

Dragićević-Šešić Milena, Rogač-Mojatović Ljiljana, 2014, Balkan Dissonant Heritage Narratives (and Their Attractiveness) for Tourism, „American Journal of Tourism Management”, 3 (1b), s. 10-19.

Geertz Clifford, 2005, Wiedza lokalna. Dalsze eseje z zakresu antropologii interpretatywnej, tłum. Dorota Wolska, Wydawnictwo Uniwersytetu Jagiellońskiego, Kraków.

Hirsch Marianne, 1997, Family Frames. Photography, Narrative, and Postmemory, Harvard University Press, Cambridge.

Hastrup Kirsten, 2008, Droga do antropologii. Między doświadczeniem a teorią, tłum. Ewa Klekot, Wydawnictwo Uniwersytetu Jagiellońskiego, Kraków.

Kaniowska Katarzyna, 2014, Postpamięć, w: Magdalena Saryusz-Wolska, Robert Traba (red.), Modi memorandi. Leksykon kultury pamięci, Scholar, Warszawa, s. 389-392.

Kapuściński Ryszard, 2013, Ten Inny, Wydawnictwo Znak, Kraków.

Macdonald Sharon, 2009, Difficult Heritage: Negotiating the Nazi Past in Nuremberg and Beyond, Routledge, London-New York.

Okoński Michał, 2019, Na łące pamięci, „Tygodnik Powszechny”, nr 15 (3640), s. 28-33.

Perec Georges, 2012, Urodziłem się. Eseje, tłum. Ewelina Kuniec, Wydawnictwo Lokator, Kraków.

Stiepanowa Maria, 2020, Pamięci pamięci, tłum. Agnieszka Sowińska, Prószyński Media, Warszawa.

Szejnert Małgorzata, 2016, Czarny ogród, Znak, Kraków.

Sznajderman Monika, 1994, Zaraza. Mitologia dżumy, cholery i AIDS, Semper, Warszawa.

Sznajderman Monika, 2014, Btazen. Maski i metafory, Iskry, Warszawa.

Sznajderman Monika, 2019, Pusty las, Wydawnictwo Czarne, Wołowiec.

Wasilewska-Klamka Beata, 2006, Łemkowski Raj Utracony. Antropologicznej studium małej ojczyzny, Fundacja Wspierania Mniejszości Łemkowskiej Rutenika, Warszawa.

Wróblewska Anna, 2017, Reportaż historyczny jako forma wspótczesnej etnografii na przykładzie Czarnego ogrodu Małgorzaty Szejnert, „Roczniki Nauk Społecznych”, t. 9 (45), nr 4, s. $145-165$. 


\section{A LATE GUEST IN A FOREIGN WORLD: CONTEXTS OF DIFFICULT HERITAGE}

Sebastian Latocha

(University of Łódź)

\section{Abstract}

In this article, the author discusses Monika Sznajderman's reportage Pusty las [The Empty Forest] in the context of Geertz's blurred genres. The author mainly addresses the condition of a person (a researcher, an anthropologist) who does not explore the Other but is the Other. In Sznajderman's book, hospitality is a basic category; the researcher studying a difficult heritage-here, the Lemko region-is a guest who must choose either to look at or to ignore the history of his or her hosts. He or she can feel at home or erase all trace of the hosts' presence. Perhaps in the end, as Maria Stepanova writes, the researcher can "breathe the air of post-memory." The author treats Sznajderman's book as an example of anthropological reportage and postulates the emergence of a new genre, on the border between the social sciences and literature.

key words: hospitality, memory, post-memory, ethnography, anthropological reportage

stowa kluczowe: gościnność, pamięć, postpamięć, etnografia, reportaż 